\title{
PENGARUH MODEL JARAK TANAM JAJAR LEGOWO TERHADAP PERTUMBUHAN DAN HASIL PADI (Oryza sativa) VARIETAS IPB 3S
}

\author{
Isromi Kurniawan, Lia Kristina, Ruly Awiyantini \\ Program Studi Agroteknologi, Fakultas Pertanian, Universitas Islam Madura \\ JL. Pondok Peantren Miftahul Ulum Bettet, Pamekasan Madura, Gladak, Bettet, Kec. \\ Pamekasan, Kabupaten Pamekasan, Jawa Timur 69317 \\ romigoki10@gmail.com
}

\begin{abstract}
ABSTRAK
Upaya peningkatan produksi pertanian dapat dilakukan dengan penggunaan varietas unggul baru dan modifikasi jarak tanam. Padi varietas IPB 3S merupakan varietas padi tipe baru yang memiliki potensi hasil mencapai $7-8$ ton/hektar serta memiliki panjang malai, bobot gabah per malai, dan bobot gabah bernas lebih tinggi daripada varietas Ciherang. Penelitian ini merupakan penelitian eksperimental menggunakan Rancangan Acak Kelompok (RAK) yang terdiri dari tiga perlakuan ditambah dengan satu kontrol (Tanpa Perlakuan) dengan tiga kali ulangan. Data yang diperoleh dianalisis dengan analisis ragam menggunakan uji F, sesuai dengan rancangan percobaan yang digunakan, selanjutnya diuji dengan Duncan's Multiple Range Test (DMRT) atau Uji Duncan untuk mengetahui perbedaan masing-masing perlakuan dengan tingkat kesalahan 5\%. Perlakuan dalam penelitian ini yaitu: P0 (Jarak Tanam Tegel), P1 (Jarak Tanam Jajar Legowo 2:1), P2 (Jarak Tanam Jajar Legowo 3:1); dan P3 (Jarak Tanam Jajar Legowo 4:1). Hasil penelitian menunjukan bahwa perlakuan jarak tanam tanam jajar legowo tidak berpengaruh terhadap tinggi tanaman dan jumlah anakan, kecuali jumlah anakan pada umur 55 HST. Namun berpengaruh nyata terhadap panjang malai dan hasil gabah kering panen. Hasil tertinggi ditunjukkan jarak tanam jajar legowo 2:1.
\end{abstract}

Kata kunci: model jarak tanam jajar legowo, padi varietas IPB 3 S

\section{PENDAHULUAN}

Usaha pertanian berkelanjutan telah menjadi perhatian dunia karena berhubungan dengan kebutuhan pangan yang terus meningkat sesuai dengan pertambahan jumlah penduduk (Arfrianto, 2010). Laju pertumbuhan jumlah penduduk masih lebih tinggi bila dibandingkan dengan laju pertumbuhan produksi padi nasional, namun, ironisnya lahan pertanian yang menjadi tumpuan penyediaan pangan untuk produksi pangan banyak mengalami degradasi akibat pengelolaan intensif dan tidak memperhatikan kelestarian lingkungan. Kondisi tersebut diperparah dengan adanya penggunaan teknologi revolusi hijau yang menyebabkan ketergantungan terhadap pupuk kimia (Sisworo, dikutip dalam Irawan \& Ariningsih, 2007). Tingginya penggunaan 
pupuk anorganik dalam jangka waktu lama dan tidak sesuai aturan dapat menyebabkan penurunan kualitas tanah atau penurunan produktivitas tanah dalam menghasilkan tanaman (Soekamto \& Fahrizal, 2019).

Fenomena lain juga sering dijumpai yaitu kebiasaan petani yang menggunakan pupuk kimia berlebihan, terutama urea. Petani di Sumenep seringkali beranggapan bahwa semakin banyak pupuk yang digunakan maka tanaman yang dihasilkan akan semakin baik, padahal kenyataannya penggunaan pupuk kimia yang berlebih dapat mengakibatkan rendahnya kandungan bahan organik tanah, menyebabkan tanaman mudah terserang penyakit, serta hasil panen menjadi tidak maksimal. Kandungan bahan organik dan nitrogen total di Pulau Madura termasuk Kabupaten Sumenep masuk kategori sangat rendah hingga rendah (Supriyadi, 2007). Hal tersebut mengakibatkan produktivitas padi di Kabupaten Sumenep hanya mencapai 6 ton/ha (BPS Kabupaten Sumenep, 2020).

Teknologi budidaya padi dengan aplikasi pupuk urea yang minimum sangat diperlukan, selain untuk mengurangi biaya produksi, penggunaan pupuk urea secara tepat dapat membantu dalam melestarikan lingkungan. Hal tersebut dapat dicapai dengan menggunakan varietas yang minim dalam kebutuhan ureanya, salah satunya adalah padi varietas IPB 3S. Padi varietas IPB 3S adalah tanaman padi varietas baru yang dirilis oleh IPB (Institut Pertanian Bogor) pada tahun 2014. Padi varietas IPB 3S ini memiliki potensi hasil mencapai 7 8 ton/hektar, lebih tinggi 1,9 - 2,9 ton/hektar dari rata-rata produktivitas nasional yang hanya 5,1 ton/ha (BPS, 2019). Varietas padi sawah IPB $3 \mathrm{~S}$ memiliki bobot gabah per malai, panjang malai, dan bobot gabah bernas lebih tinggi daripada varietas Ciherang (Anisa, Wati, Aswidinnoor, Surahman, \& Aria, 2019). Selain itu, padi varietas IPB $3 \mathrm{~S}$ juga memiliki beberapa kelebihan lain, misalnya tak membutuhkan banyak air dan pupuk urea (Agustinus, 2016).

Produktivitas yang dihasilkan padi varietas IPB $3 \mathrm{~S}$ dapat dimaksimalkan dengan melakukan budidaya menggunakan sistem tanam jajar legowo. Sistem tanam jajar legowo adalah upaya dalam meningkatkan populasi tanaman padi dengan cara mengatur jarak tanam. Sistem tanam ini memanipulasi tata letak tanaman, sehingga rumpun tanaman sebagian besar menjadi tanaman pinggir. Cara tanam jajar legowo berpeluang menghasilkan gabah lebih tinggi dibandingkan dengan cara tanam tegel melalui populasi yang lebih banyak, varietas yang lebih adaptif pada 
kondisi pertanaman rapat, yang ditunjukkan oleh dengan rendahnya penurunan hasil akibat ditanam rapat dibandingkan cara tanam biasa/tegel (Pratiwi, Paturrohman, \& Makarim, 2013). Keuntungan dari sistem tanam jajar legowo adalah menjadikan semua tanaman atau lebih banyak tanaman menjadi tanaman pinggir. Tanaman pinggir akan memperoleh sinar matahari yang lebih banyak dan sirkulasi udara yang lebih baik, unsur hara yang lebih merata, serta mempermudah pemeliharaan tanaman (Misran, 2014).

Penelitian penerapan sistem tanam jajar legowo ini masih belum banyak dilakukan di Sumenep, sehingga perlu dilakukan penelitian untuk mengetahui apakah sistem tanam jajar legowo memberikan pengaruh terhadap tinggi tanaman, jumlah anakan, jumlah malai per rumpun, panjang malai per rumpun, dan jumlah produksi. Padi varietas IPB 3S ini dipilih karena memiliki potensi hasil mencapai $7-8$ ton/hektar, lebih tinggi 1,9 $-2,9$ ton/hektar dari rata-rata produktivitas nasional yang hanya 5,1 ton/ha (BPS, 2019). Disamping itu, varietas IPB 3S juga sering ditanam oleh salah satu Kelompok Wanita Tani di Kecamatan Guluk-Guluk Kabupaten Sumenep, yaitu KWT. AlBana. Untuk meningkatkan produktivitas padi, kelompok wanita tani tersebut berusahatani padi varietas IPB $3 \mathrm{~S}$ dengan perlakuan jarak tanam jajar legowo 2:1, namun belum mencoba sistem jajar legowo model 3:1 maupun 4:1. Dalam penelitian ini, dilakukan perbandingan antar sistem jajar legowo untuk mengetahui sistem jajar legowo mana yang paling berpengaruh pertumbuhan dan produksi tanaman padi varietas IPB $3 \mathrm{~S}$.

\section{Perumusan Masalah}

Berdasarkan latar belakang tersebut, maka perumusan masalah dalam peneltian ini adalah apakah terdapat pengaruh sistem tanam jajar legowo pada pertumbuhan dan hasil padi varietas IPB $3 \mathrm{~S}$.

\section{Tujuan Penelitian}

Penelitian ini bertujuan untuk menganalisis pengaruh sistem tanam jajar legowo terhadap pertumbuhan dan hasil padi varietas IPB $3 \mathrm{~S}$

\section{Manfaat Penelitian}

Manfaat penelitian ini diharapkan menjadi sumber informasi baik secara teoritis maupun praktis, diantaranya sebagai berikut:

1. Penelitian ini diharapkan dapat memberikan manfaat sebagai karya ilmiah dan sumber referensi untuk menambah pengetahuan dan keilmuan dalam bidang Agroteknologi khususnya 
pada bidang perencanaan sistem tanam untuk tanaman padi; dan

2. Hasil penelitian ini diharapkan dapat memberikan rekomendasi mengenai perencanaan sistem tanaman untuk tanaman padi untuk meningkatkan produktivitas, efisiensi usaha tani serta meningkatkan pendapatan petani.

\section{METODE PENELITIAN}

Penelitian ini dilaksanakan di areal lahan sawah pertanaman padi varietas IPB 3S Kelompok Wanita Tani Al-Banna di Desa Bragung Kecamatan Guluk-Guluk Kabupaten Sumenep dengan koordinat $7,04612^{\circ} \mathrm{LS}$ dan $113,66059^{\circ} \mathrm{BT}$ yang berada pada ketinggian 137,2 $\mathrm{m}$ di atas permukaan laut. Penelitian dilakukan dari Bulan Maret hingga bulan Juni 2021.
Metode penelitian yang digunakan pada penelitian ini adalah penelitian eksperimental menggunakan Rancangan Acak Kelompok (RAK) yang terdiri dari tiga perlakuan ditambah dengan satu kontrol (Tanpa Perlakuan) sehingga total ada empat perlakuan dengan tiga kali ulangan, dengan jumlah 12 petak percobaan. Perlakukan sistem tanam dalam penelitian ini yaitu:

a) P0 = Jarak Tanam Tegel $(20 \times 20) \mathrm{cm}^{2}$

b) P1 = Jarak Tanam Jajar Legowo 2:1 (40

$$
\text { x } 20 \times 20 \times 12,5) \mathrm{cm}^{2}
$$

c) P2 = Jarak Tanam Jajar Legowo 3:1 (40

$$
\text { x } 20 \times 20 \times 20 \times 12,5) \mathrm{cm}^{2}
$$

d) P3 = Jarak Tanam Jajar Legowo 4:1 (40

$$
\text { x } 20 \times 20 \times 20 \times 20 \times 12,5) \mathrm{cm}^{2}
$$

Adapun denah dari penelitian dari masing-masing perlakuan dengan tiga kali ulangan sebagai berikut:

Ulangan I Ulangan II Ulangan III

\begin{tabular}{|c|c|c|}
\hline P1 & P0 & P3 \\
\hline P0 & P1 & P2 \\
\hline P2 & P3 & P1 \\
\hline P3 & P2 & P0 \\
\hline
\end{tabular}

Data yang diperoleh dianalisis dengan analisis ragam menggunakan uji $\mathrm{F}$, sesuai dengan rancangan percobaan yang digunakan, selanjutnya diuji dengan Duncan's Multiple Range Test (DMRT) atau Uji Duncan untuk mengetahui perbedaan masing-masing perlakuan dengan tingkat kesalahan 5\%. 
HASIL DAN PEMBAHASAN

Tinggi Tanaman dari Beberapa Model Sistem Tanam Jajar Legowo

Hasil Analisis Ragam/Analysis of Variance (Anova) satu arah (one way) dari perlakuan maupun ulangan pengaruh model tanam tegel dan jajar legowo terhadap tinggi tanaman padi tidak signifikan (Nilai Sig. > 0,05), baik pada umur 28 HST, 42 HST, maupun 55 HST. Untuk lebih lengkapnya, hasil rerata tinggi tanaman akibat pengaruh perlakuan jarak tanam tegel dan jajar legowo disajikan dalam

Tabel 1.

Tabel 1. Rerata Tinggi Tanaman dengan Perlakuan Jarak Tanam Tegel dan Jajar Legowo

\begin{tabular}{lccc}
\hline \multirow{2}{*}{ Perlakuan Jarak Tanam } & \multicolumn{3}{c}{ Rerata Tinggi Tanaman } \\
& 28 HST & 42 HST & 55 HST \\
\hline P0 (Jarak Tanam Tegel) & $74,10 \mathrm{a}$ & $98,63 \mathrm{a}$ & $117,10 \mathrm{a}$ \\
P1 (Jarak Tanam Jajar Legowo 2:1) & $78,30 \mathrm{a}$ & $96,03 \mathrm{a}$ & $114,50 \mathrm{a}$ \\
P2 (Jarak Tanam Jajar Legowo 3:1) & $76,43 \mathrm{a}$ & $95,30 \mathrm{a}$ & $116,43 \mathrm{a}$ \\
P3 (Jarak Tanam Jajar Legowo 4:1) & $78,83 \mathrm{a}$ & $98,70 \mathrm{a}$ & $114,43 \mathrm{a}$ \\
\hline
\end{tabular}

Keterangan: Angka-angka yang diikuti oleh huruf yang sama berarti berbeda tidak nyata

Berdasarkan data pada Tabel 1, dapat dilihat bahwa pengaruh perlakuan jarak tanam tegel dan jajar legowo terhadap tinggi tanaman padi tidak berbeda nyata baik pada umur 28 HST, 42 HST, dan 55 HST. Hal ini menunjukkan bahwa dengan perlakuan jarak tanam tidak akan memberikan pengaruh yang nyata terhadap tinggi tanaman padi. Secara diagram balok, juga terlihat perlakuan jarak tanam tidak nampak berpengaruh nyata terhadap tinggi tanaman (Gambar 1) 


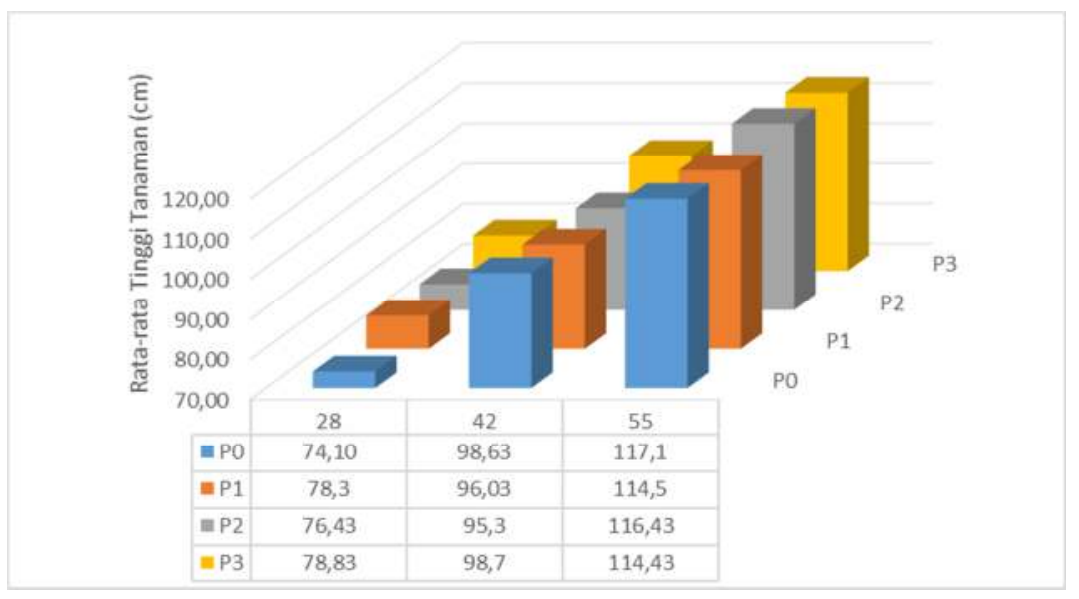

Gambar 1. Rerata Tinggi Tanaman Akibat Perlakuan Jarak Tanam

Pendapat dari Abdulrachman et al., (2013), yang menyatakan jarak tanam jajar legowo mempunyai kelebihan, yaitu: tanaman akan lebih mudah dalam memperoleh cahaya matahari, lebih mudah dalam pemupukan, penyiangan, pengendalian OPT, maupun berpeluang dapat meningkatkan produktivitas tanaman karena jumlah populasinya bertambah, namun tetap tidak berpengaruh terhadap tinggi tanaman.

\section{Jumlah Anakan dari Beberapa Model Sistem Tanam Jajar Legowo}

Rerata jumlah anakan akibat perlakuan beberapa model jarak tanam tidak menunjukkan perbedaan yang signifikan (Nilai Sig. $>0,05$ ) pada umur 28 HST dan 42 HST, namun berbeda nyata pada umur 55 HST (Lampiran 2). Secara lebih rinci, rerata jumlah anakan dalam Analisis uji Duncan 5\% seperti pada Tabel 2.

Tabel 2. Rerata Jumlah Anakan dengan Perlakuan Jarak Tanam Tegel dan Jajar Legowo dengan Hasil Uji Duncan 5\%

\begin{tabular}{lccc}
\hline \multirow{2}{*}{ Perlakuan Jarak Tanam } & \multicolumn{3}{c}{ Rerata Jumlah Anakan } \\
& 28 HST & 42 HST & 55 HST \\
\hline P0 (Jarak Tanam Tegel) & $9,77 \mathrm{a}$ & $10,23 \mathrm{a}$ & $10,23 \mathrm{ab}$ \\
P1 (Jarak Tanam Jajar Legowo 2:1) & $11,97 \mathrm{a}$ & $12,90 \mathrm{a}$ & $10,57 \mathrm{a}$ \\
P2 (Jarak Tanam Jajar Legowo 3:1) & $10,63 \mathrm{a}$ & $11,03 \mathrm{a}$ & $10,13 \mathrm{~b}$ \\
P3 (Jarak Tanam Jajar Legowo 4:1) & $10,43 \mathrm{a}$ & $10,87 \mathrm{a}$ & $10,17 \mathrm{~b}$ \\
\hline
\end{tabular}

Keterangan: Angka-angka yang diikuti oleh huruf yang sama berarti berbeda tidak nyata menurut uji duncan $5 \%$ 
Dari data Tabel 2, dapat dijelaskan bahwa perlakuan jarak tanam pada umur 28 HST dan 42 HST tidak berpengaruh nyata, namun berpengaruh nyata pada umur 55 HST menurut Uji Duncan 5\%. Perlakuan jarak tanam terbaik terdapat pada P1 (jarak tanam jajar legowo 2:1), kemudian berikutnya perlakuan P0 (jarak tanam tegel), sedangkan P2 (jarak tanam jajar legowo 3:1) dan P3 (jarak tanam jajar legowo 4:1) merupakan perlakuan yang memberikan pengaruh jumlah anakan terendah. Pada diagram batang Gambar 8, nampak adanya perbedaan pada jumlah anakan akibat perlakuan jarak tanam, namun yang berpengaruh nyata hanya pada umur 55 HST.

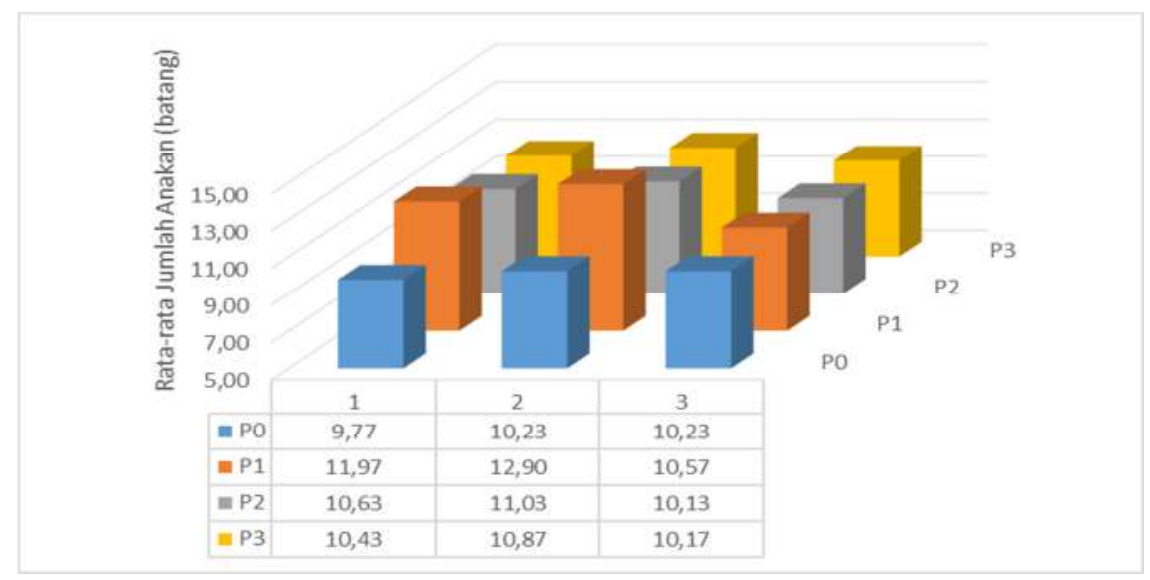

Gambar 2. Rerata Jumlah Anakan Akibat Perlakuan Jarak Tanam

Perlakuan P1 merupakan perlakuan terbaik dalam variabel jumlah anakan produktif pada umur 55 HST. Hal ini dikarenakan sifat genetik dari padi varietas IPB 3S yang hanya mempunyai potensi jumlah anakan produktif 7-12 batang (Anisa, Wati, Aswidinnoor, Surahman, \& Aria; 2019). Perlakuan P1 mempunyai jumlah populasi tanaman per ha lebih sedikit dibandingkan P2 dan P3, maka anakan tanaman akan tumbuh dan berkembang dengan maksimal. Untuk perlakuan P0 semua tanaman seolah-olah tidak menjadi tanaman pinggir seperti kelebihan sistem tanam jajar legowo pada umumnya, sehingga jumlah anakannya lebih rendah dari perlakuan P1.

Panjang Malai dan Jumlah Bulir Per Malai dari Beberapa Model Sistem Tanam Jajar Legowo

Hasil analisis ragam pengaruh jarak tanam terhadap panjang malai menunjukkan perbedaan yang nyata (Nilai Sig. $<0,05)$, sedangkan terhadap jumlah bulir per malai tidak berpengaruh secara 
signifikan (Nilai Sig. > 0,05) (Lampiran 3).

Untuk mengetahui bagaimana pengaruhnya masing-masing perlakuan terhadap panjang malai dan jumlah bulir per malai menurut Uji Duncan 5\%, disajikan pada Tabel 3.

Tabel 3. Rerata Panjang Malai dan Jumlah Bulir Per Malai dengan Perlakuan Jarak Tanam Tegel dan Jajar Legowo dengan Hasil Uji Duncan 5\%

\begin{tabular}{lcc}
\hline \multicolumn{1}{c}{ Perlakuan Jarak Tanam } & $\begin{array}{c}\text { Rerata Panjang } \\
\text { Malai }\end{array}$ & $\begin{array}{c}\text { Rerata Jumlah } \\
\text { Bulir Per Malai }\end{array}$ \\
\hline P0 (Jarak Tanam Tegel) & $25,90 \mathrm{a}$ & $213,70 \mathrm{a}$ \\
P1 (Jarak Tanam Jajar Legowo 2:1) & $26,27 \mathrm{a}$ & $214,20 \mathrm{a}$ \\
P2 (Jarak Tanam Jajar Legowo 3:1) & $25,03 \mathrm{~b}$ & $212,10 \mathrm{a}$ \\
P3 (Jarak Tanam Jajar Legowo 4:1) & $24,73 \mathrm{~b}$ & $208,47 \mathrm{a}$ \\
\hline
\end{tabular}

Keterangan: Angka-angka yang diikuti oleh huruf yang sama berarti berbeda tidak nyata menurut uji duncan $5 \%$

Perlakuan P1 menunjukkan panjang malai terbaik, namun tidak berbeda nyata dengan P0, sedangkan perlakuan P2 (jarak tanam jajar legowo 3:1) dan P3 (jarak tanam jajar legowo 4:1) merupakan perlakuan terendah dalam variabel panjang malai. Pengaruh perlakuan jarak tanam juga terlihat secara grafik batang pada Gambar 3, dimana perlakuan P0 dan P1 merupakan perlakuan yang terbaik.

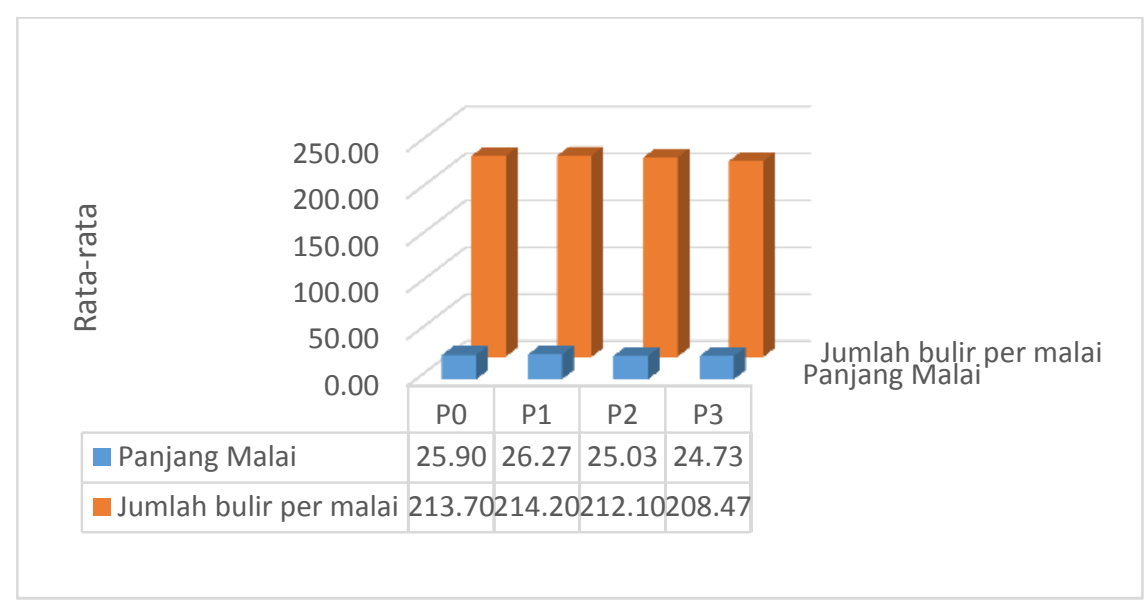

Gambar 3. Rerata Panjang Malai dan Jumlah Bulir Per Malai Akibat Perlakuan Jarak Tanam

Varietas padi IPB 3S memiliki malai panjang yang dapat menghasilkan 300-350 bulir gabah per malai. Ukuran bulir lebih besar sehingga bobot per 1.000 bulir mencapai 28 gram (Ansari, 2014). Hal ini yang menyebabkan perlakuan P0 dan P1 
merupakan perlakuan terbaik dibandingkan P2 dan P3, karena padi IPB 3S membutuhkan jarak tanam yang agak lebar agar potensi yang ada, terutama malai dan bulir padi dapat tumbuh dan berkembang dengan baik.
Produksi Per Ha (Gabah Kering Panen, GKP) dari Beberapa Model Sistem Tanam Jajar Legowo

Menurut hasil analisis ragam, menunjukkan perlakuan jarak tanam jajar legowo memberikan pengaruh yang signifikan (Nilai Sig. $<0,05)$ terhadap produksi per ha $(\mathrm{GK})$. Analisis lebih lanjut dengan menggunakan uji Duncan 5\% disajikan pada Tabel 4.

Tabel 4. Rerata Produksi Per Ha (Ton, GKP) dengan Perlakuan Jarak Tanam Tegel dan Jajar Legowo dengan Hasil Uji Duncan 5\%

\begin{tabular}{lc}
\hline Perlakuan Jarak Tanam & Produksi Per Ha (Ton, \\
& GKP) \\
\hline P0 (Jarak Tanam Tegel) & $5,37 \mathrm{a}$ \\
P1 (Jarak Tanam Jajar Legowo 2:1) & $5,38 \mathrm{a}$ \\
P2 (Jarak Tanam Jajar Legowo 3:1) & $5,23 \mathrm{ab}$ \\
P3 (Jarak Tanam Jajar Legowo 4:1) & $5,18 \mathrm{~b}$ \\
\hline
\end{tabular}

Keterangan: Angka-angka yang diikuti oleh huruf yang sama berarti berbeda tidak nyata menurut uji duncan $5 \%$

Perlakuan P1 menunjukkan hasil gabah kering panen tertinggi dibandingkan dengan perlakuan lainnya, namun tidak berbeda nyata dengan perlakuan P0, selanjutnya diikuti oleh perlakuan P2 (jarak tanam jajar legowo 3:1) dan P3 (jarak tanam jajar legowo 4:1) (Tabel 4). Dari grafik batang pada Gambar 14, juga terlihat bahwa perlakuan P0 dan P1 merupakan perlakuan yang terbaik. 


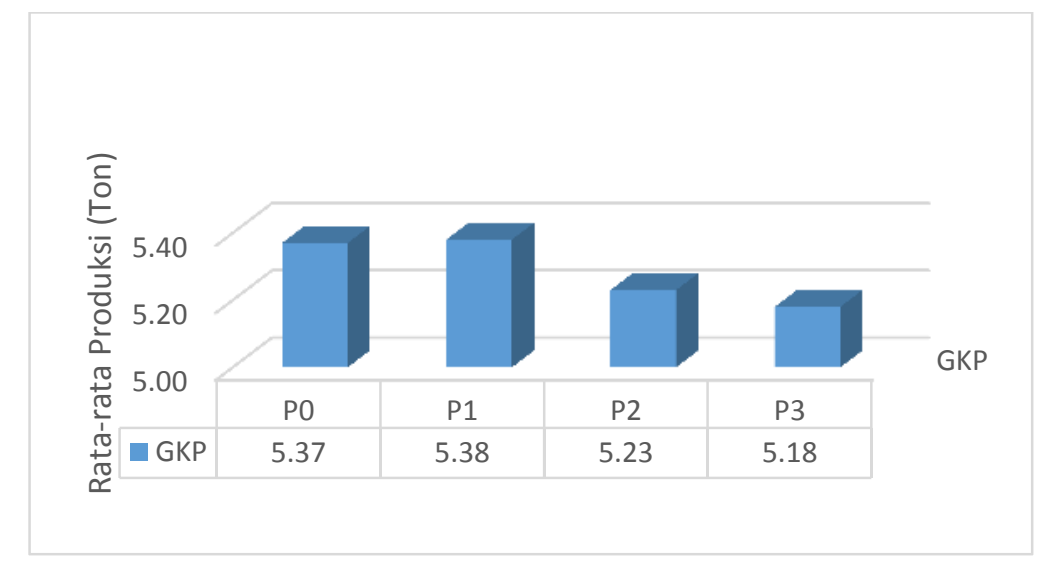

Gambar 4. Rerata Produksi Per Ha (Ton) Akibat Perlakuan Jarak Tanam

Tingginya hasil gabah pada perlakuan P1 (Jarak Tanam Jajar Legowo 2:1) disebabkan penyerapan unsur hara dan cahaya matahari bisa maksimal dan adanya kemudahan dalam pengelolaan usahatani, seperti pemupukan susulan, penyiangan, pelaksanaan pengendalian hama dan penyakit (Abdulrachman et al., 2013), serta kesesuaian dengan sifat genetik atau potensi yang ada pada padi varietas IPB 3S yang lebih membutuhkan jarak tanam yang lebih lebar (Anisa, Wati, Aswidinnoor, Surahman, \& Aria; 2019).

\section{KESIMPULAN}

Berdasarkan hasil penelitian pengaruh model jarak tanam jajar legowo terhadap pertumbuhan dan hasil padi (Oryza sativa) varietas IPB 3S, maka dapat diambil kesimpulan bahwa perlakuan jarak tanam tanam jajar legowo tidak berpengaruh terhadap tinggi tanaman dan jumlah anakan, kecuali jumlah anakan pada umur 55 HST, namun berpengaruh nyata terhadap panjang malai dan hasil gabah kering panen. Hasil tertinggi ditunjukkan jarak tanam jajar legowo $2: 1$.

\section{DAFTAR PUSTAKA}

Abdulrachman, D. S., Mejaya, D. M. J., Nurwulan Agustiani, S., Indra Gunawan, S., Sasmita, D. P., \& Guswara, I. A. (2013). Sistem Tanam Legowo. Badan Penelitian dan Pengembangan Pertanian. Sukabumi.

Agustinus, M. 2016. Padi Buatan IPB Ini Produktif, Hemat Air, dan 'Tahan Banting'. Terdapat pada: https://finance.detik.com/beritaekonomi-bisnis/d-3368120/padi-buatanipb-ini-produktif-hemat-air-dan-tahanbanting. Diakses tanggal 2 Maret 2021 
pukul 09.36 WIB

Anisa, T., Wati, P., Aswidinnoor, H., Surahman, M., \& Aria, D. (2019). Demonstrasi Plot Padi IPB $3 S$ dan IPB $9 G$ sebagai Upaya Peningkatan Pengetahuan Petani Desa Mekarharja, Kecamatan Purwaharja, Kota Banjar (Demonstration Rice Plot Of IPB $3 S$ and IPB $9 G$ in an Effort Farmers ' Knowledge in Mekarharja Village, Purwaharja District Banjar City). 1(November), 37-43.

Ansari, H. .2014. Kandungan Unsur Hara Tanah serta Produksi Padi Sawah Pada Sistem Tanam SRI (System of Rice Intensification). Jurnal Online Agroekoteknologi, 2(2337), 1048-1055. Arfrianto, D. 2010. Analisis Pengaruh Stok Beras, Luas Panen, Rata-Rata Produksi, Harga Beras, dan Jumlah Konsumsi Beras Terhadap Ketahanan Pangan di Jawa Tengah.

Badan Pusat Statistik Kabupaten Sumenep. 2020. Sumenep dalam Angka. Sumenep: Badan Pusat Statistik.

Badan Pusat Statistik. 2019. Luas Panen dan Produksi Padi di Indonesia 2019. Jakarta Pusat: Badan Pusat Statistik.

Irawan, B., \& Ariningsih, E. 2007. Dinamika penerapan teknologi pertanian pada tipe desa berbasis padi sawah, palawija, dan sayuran. (4), 129152.

Malik, N. 2014. Pertumbuhan Tinggi Tanaman Sambiloto (Andrographis Paniculata Ness) Hasil Pemberian Pupuk dan Intensitas Cahaya Matahari yang berbeda. Jurnal Agroteknos, 4: 189-193.

Misran. 2014. Studi Sistem Tanam Jajar Legowo terhadap Peningkatan Produktivitas Padi Sawah The s tudies of row planting system "L egowo " to the increased productivity of lowland rice Misran. 14(2), 106-110.

Prasetyo, O.R. 2019. Teknik Penanaman Jajar Legowo untuk Peningkatan Produktivitas Padi Sawah di Jawa Tengah. Jurnal Litbang Sukowati. Vol. 3 No. 1.

Pratiwi, G. R., Paturrohman, E., \& Makarim, A. K. 2013. Peningkatan Produktivitas Padi Melalui Penerapan Jarak Tanam Jajar Legowo. 72-79.

Purnamaningsih, R. 2006. Induksi Kalus dan Optimasi Regenerasi Empat Varietas Padi Melalui Kultur In Vitro. Balai Besar Penelitian dan Pengawasan Bioteknologi dan Sumber Daya Genetik Pertanian. Bogor. Jurnal AgroBiogen 2(2):74-80 
Rouw, A. 2008. Analisis Dampak Keragaman Curah Hujan Terhadap Kinerja Produksi Padi Sawah (Studi Kasus di Kabupaten Merauke Papua). J. Pengkajian dan Pengembangan Teknologi Pertanian. 11(2) : 146-155.

Soekamto, M. H., \& Fahrizal, A. 2019. Upaya Peningkatan Kesuburan Tanah Pada Lahan Kering Di Kelurahan Aimas Distrik Aimas Kabupaten Sorong Mira. 1, 14-23.

Sulistyawati, E., dkk. 2010. Efektivitas Kompos Sampah Perkotaan Sebagai Pupuk Organik dalam Meningkatkan Produktivitas dan Menurunkan Biaya Produksi Budidaya Padi. Sekolah Tinggi Ilmu \& Teknologi Hayati. Institut Teknologi Bandung. Bandung. 10 hal.

Supriyadi, S. 2007. Kesuburan Tanah di Lahan Kering Madura. 4(2), 124-131.

Syahri, \& Somantri, R. U. 2016. Penggunaan Varietas Unggul Tahan Hama dan Penyakit Mendukung Peningkatan Produksi Padi Nasional The Use of Improved Varieties Resistant to Pests and Diseases to Increase National Rice Production. 25-36. 